\title{
急性腎孟内圧上昇時に扮ける腎内血流分布の変化に関する研究
}

\author{
秋田大学医学部泌尿器科高田斉
}

\section{THE EFFECTS OF THE RENAL PELVIC PRESSURE ELEVATION UPON LOCAL RENAL BLOOD FLOW DISTRIBUTION}

\author{
Hitoshi Takada \\ Department of Urology, Akita University School of Medicine \\ (Director: Prof. S. Tsuchida)
}

The effects of fast elevation of intra-pelvic pressure on total renal blood flow (RBF) and local renal blood flow were studied in 34 mongrel dogs anesthetized with pentobarbital, including 4 dogs given mannitol beforehand. The RBF was measured by an electromagnetic flow meter, and local blood flow by two methods based on differing principles: the hydrogen-gas clearance method and the heat electrical method.

1) In the dogs without mannital administration, during the elevation of pevic pressure an increase in $\mathrm{RBF}$ was observed in the increase of $\mathrm{RBF}$ in the groups with low grade ( $25 \mathrm{mmHg}$ ) and high grade $(75 \mathrm{mmHg})$ pelvic ressure elevation.

Cortical and medullary blood flow decreased as measured by the hydrogen-gas clearance method, and cortical blood flow increased as measured by the heat electrical method, in high grade pelvic pressure elevation. This seemed to be caused by the flow directly returning to the renal vein, resulting in a retardation of the Vasa Recta's flow.

2) After the mannitol infusion, an increase in RBF and cortical and medullary flow was observed by both methods. Following the administration of mannitol, unilateral ureteral ligation brougth about a decrease of ipsilateral RBF and cortical and medullary flow.

3) In the group without mannitol administration, the blood flow returned to the pre-elevated pelvic pressure level after release of the ureteral occlusion. In the group given mannitol, recovery of blood flow did not occur.

4) Through the results measured by the two different methods, the non-nutrient blood flow seemed to be the important part of the hemodynamic response of the obstructed kidney.

\footnotetext{
要旨：急性腎孟内圧上昇時に拈ける，腎皮質および䯣質の循環動態の解明を目的とし，各種条件下にお ける腎動脈血流量（RBF），皮質および髄質血流量（CBF, MBF）の変化を調べ，その腎機能に及ぼす 影響について検討した。

雑種成犬を用いて，一側腎につき急激に腎孟内圧を上昇拉よび下降させることにより， RBF， CBF， MBF はいずれも大きく変動するが, 組織血流量測定に水素クリアランス法と熱電対法を併用したこと から，いわゆる non-nutrient flow が閉塞腎の血行動態に大きく関与していると考えられた. また，マニ トール負荷により RBF とともに皮質, 䯣質の組織血流が増加したが, これは従来からの wash ont theoryを裏づけるものと思われた. 更にマニトール負荷のもとに尿管を結禁拉よび解除することにより,こ のような操作が腎機能に対し, 非可逆的な変化をもたらしているとの推論に達した.
}

\section{緒 言}

腎盂もしくは尿管内圧はさまざまな原因により上昇 する。臨床的には，尿管結石の嵌頓，高度の膀胱尿管 逆流 (以下 VUR), 外科的操作扔よび異常血管による
腎孟もしくは尿管の閉塞の場合に経験されるものであ る. しかし腎孟内圧の変化が, 尿生成の大きな因子で ある腎の血流動態に対して，どのような影響を与兄る

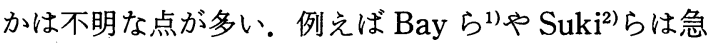


激な尿管内圧の上昇は䯣質血流を増加させるとしてお り, Selkurt ${ }^{3)} ら$ も，早期にはやはり䯣質血流が増加す るとしている。その他にも文献的には相反する様々な

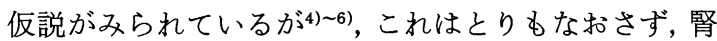
の組織内血流量, 特に腎髄質血流量測定の困難さに由 来しているためであり，また実験に使用される動物の 種類の違いや，実験条件の差異が異った結果をもたら したようである。

ところで，尿管に結石が嵌頓する場合，腎孟内圧が 急激に上昇する場合と，徐々に上昇する場合があり， 後者に抢ける腎血流量, 腎内血流分布の変化について は前述した報告の他にもいくつかの報告がある7 8). しかし，VUR の場合，膀胱内圧と同等の強い圧力が腎 孟に負荷され, 腎盂内圧が $50 \mathrm{mmHg}$ 以上に急激に上昇 する場合もある。

そこで，私は腎孟内圧の急激な上昇が腎の局所血流 にどのような影響を与えるかを調べるため雑種成犬を 用いて以下の実験を行った。すなわち，種々の条件下 により腎孟内圧を上昇させたときの圧上昇前後におけ る腎動脈血流量，腎の皮質および髄質の組織血流量の 変化を, 水素クリアランス法と熱電対法により測定し, 二，三の知見を得たので報告する.

\section{実験対象および方法}

\section{(1) 実験材料}

体重5～20kg の雑種成犬34頭を用いた。飼料には固 形飼料（Na $0.34 \mathrm{~g} / 100 \mathrm{~g}$ を含有）1 日量として $350 ５ 00 \mathrm{~g}$ を与文，実験当日は朝より絶食とした。

(2) 麻酔

ペントバルビタール $25 \mathrm{mg} / \mathrm{kg}$ で全身麻酔し, 全例気 管内插管後レスピレーター（アイカR-60）による調節 呼吸を行った。

（3）実験装置

実験方法の概略は図 1 亿示すと拈りである，血圧は $16 \mathrm{G}$ メディカットを大腿動脈もしくは上腕動脈に留置 し，圧トランスジューサー（日本光電製 MPU-0.5）に より測定し，ポリグラフに描出して変動を調べた。腎 動脈血流量 (以下 RBF) は腹部大動脈より左腎動脈が 分岐した直後の部分に電磁流量計（日本光電製 MF26）を装置し，同様に血流変動をポリグラフに描出さ せた。

（4）腎孟内圧を上昇させる方法

2 種類の方法すなわち直接腎掹加圧法（群）と， 、 ニトール負荷加圧法（群）である。 まず直接腎孟加圧 法（群）について述べる。すなわち図 1 に示すように
図 1 実験方法略図

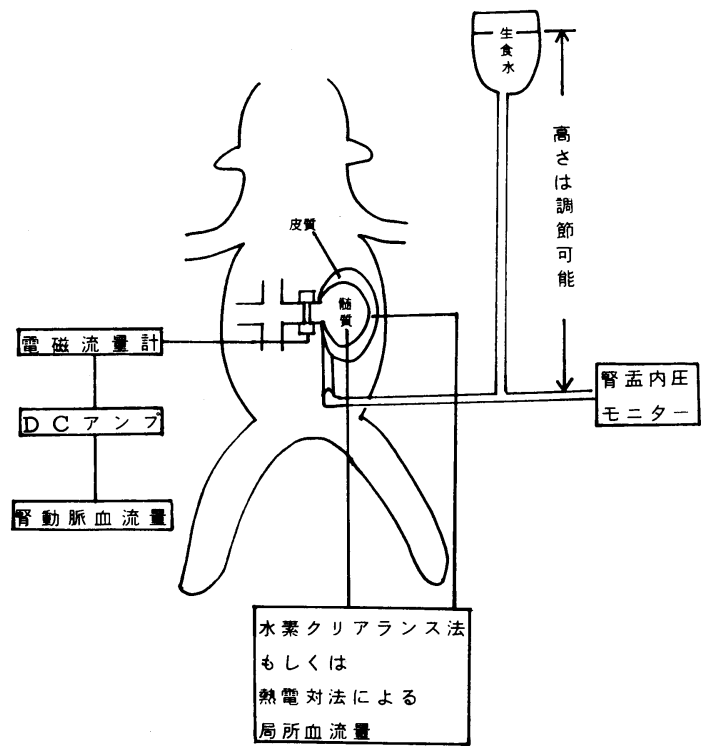

左側中部尿管に小切開を加光, 同部よりアトム製 5 号 栄養カテーテルを腎典内に插入し，尿管の切開部より 末梢側尿管は結紮した。 カテーテルにはT字管を接続 させ，その一方より腎盂内圧をモニターし，他方には 右心房の高さを 0 として, 25, 50,75mmHg の圧が加 わるように高さの調節できる生理的食塩水の入った ガートルを連結した。

マニトール負荷法（群）では，マニトール $20 \%$ 溶液 を $2 \mathrm{~g} / \mathrm{kg}$ 点滴静注して, 高度の浸透圧利尿の状態とし てから, 左側中部尿管を結紮し, 結禁部より上方に小 切開を加えてカテーテルを腎孟内に挿入し, 腎孟内圧 をモニターした。

（5）局所血流量の測定法

組織血流量の測定は水素クリアランス法と熱電対法 により行った。

水素クリアランス法には, 水素ガスボンベ, 白金一白 金黒電極, 不関電極 (銀, 塩化銀電極), 組織水素濃度 測定装置 UHメーター, UHG-Unique Medical 201, および記録計を使用した。

具体的測定操作法を述べると, 先端近くの白金黒を 塗布した約 $0.6 \mathrm{~mm}$ を除いてェナメルコーティングさ れている直径 $100 \mu$ の白金線を使用し，その先端部分を 左腎の皮質拉よび髄質外層に刺入した後, 約 $10 \%$ の水 素ガスを含む空気をレスピレータ内に送り，平均約 25 秒で局所血流中の水素濃度を飽和させた後, 水素ガス の吸入を中止した。得られる水素クリアランス曲線は 
図 2 水素クリアランス曲線

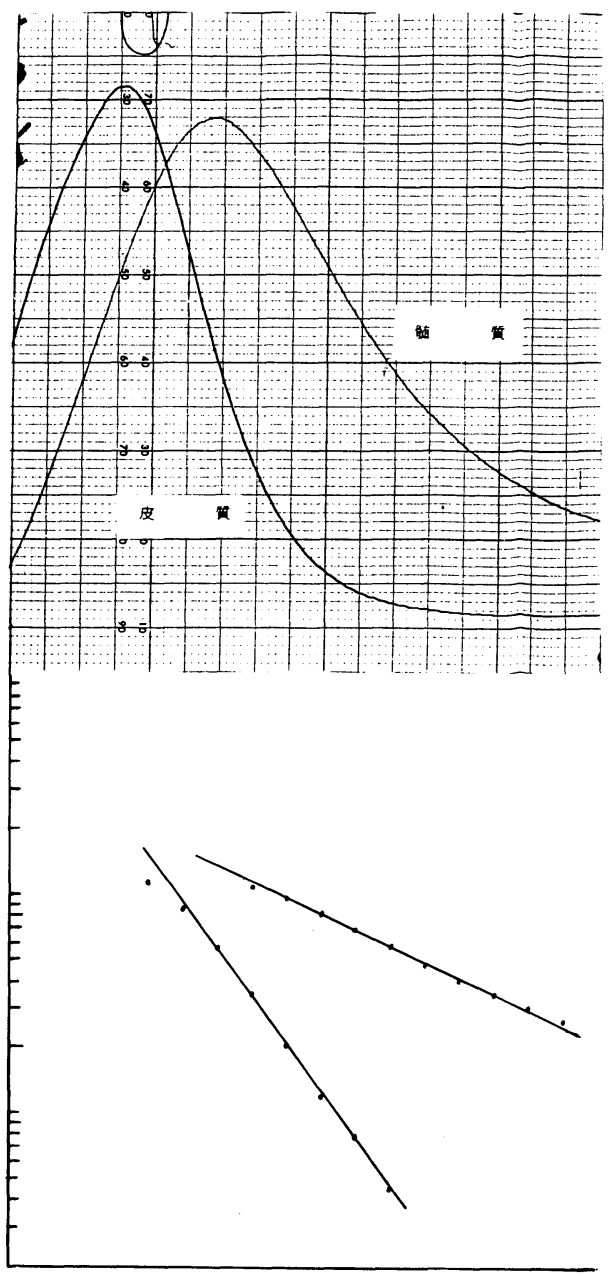

図 2 -上に示すような曲線になり, この曲線上の值を片 対数に，時間を横軸に plotすると図 2 -下のような直 線が得られる。この直線より水素ガス濃度の半減時間 (T1/2)を求め, 表 1 により腎の単位重量当りの組織血 流量を計算した。

な打本法では常に問題となるのが電極先端の插入位 置であるが, 私の実験では同じ条件下では皮質, 髄質 それぞれ平均的な測定值が得られた，実験にあたって は, 電極位置確認のため, 実験終了直後に被験腎を摘 出, 腎の総重量, 皮質, 髄質それぞれの重量を測定し 皮質の厚さも確認した。

熱電対法には, Unique Medical 製 UM-2000を使用 し, element にはダブルニードルタイプの WN 501を 使用した。

測定の操作法を述べると図 3 に示すような element

\section{表 1}

血流量算出計算方法( kety ${ }^{(15)}$ の理諞式にもとすくく)

(1) $\mathrm{Ci}=\mathrm{Ci}$. $e^{-\frac{F}{\lambda w}}=\mathrm{C} i \circ . e^{-\frac{k}{\lambda} \cdot t}$

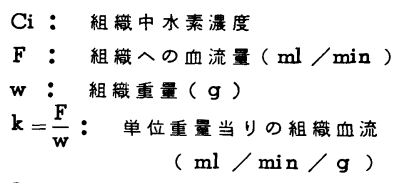

Cio: クリア開始時の組織中水素浱度

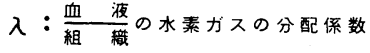

$\mathbf{t}$ ： 時間 ( $\min )$

(2) $\mathrm{K}=-\frac{\lambda \cdot \log e^{\frac{1}{2}}}{\mathrm{~T} 1 / 2}$

$$
=\frac{\lambda \times 0 \cdot 693}{T^{1 / 2}}(\mathrm{ml} / \mathrm{min} / \mathrm{g})
$$

$\mathrm{T} 1 / 2$ : Ci が初めの值Ci。の $\frac{1}{2}$ に減少する

に要する時間

（3） $\mathrm{K}=\frac{0.693}{\mathrm{~T} 1 / 2}(\lambda=1$ とした場合）

* Kの值は $\mathrm{H}_{2}$ - desaturation curve

を片対数にブロットして得られる傾きから

求めることがてきる。

図 3 熱電対法に用いる電極

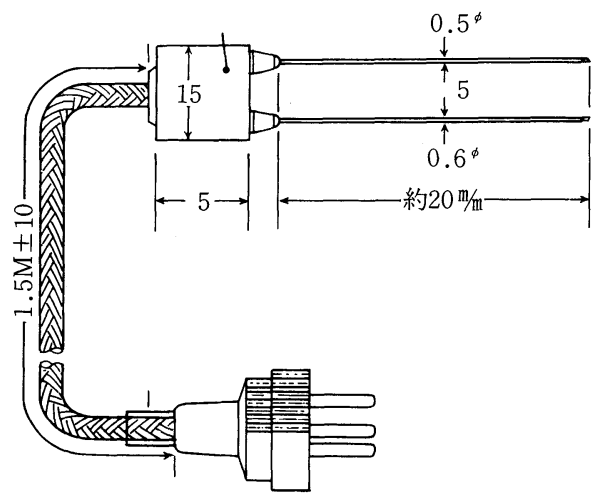

基準側 加温側

を血圧などの測定の前に皮質, 髄質に刺入し, その際 element の加温側と対応点の深さが同じであるょうに 注意して, 血圧, 腎血流量などが安定した時点の血流 量を $100 \%$ とし，実験終了時に腎動静脈を遮断した時点 での血流量を 0 とし，その間の変化を百分率で表示し た. 従って血流量は絶対値としては算定されず, 相対 的な変化として表わされた（図4）.

なお二法による測定值を区別するために，水素クリ 
図 4 熱電対法より得られる血流量の変化 上段一 $\mathrm{RBF}$, 中段一 $\mathrm{CBF}(\mathrm{Th})$, 下段一 $\mathrm{MBF}(\mathrm{Th})$
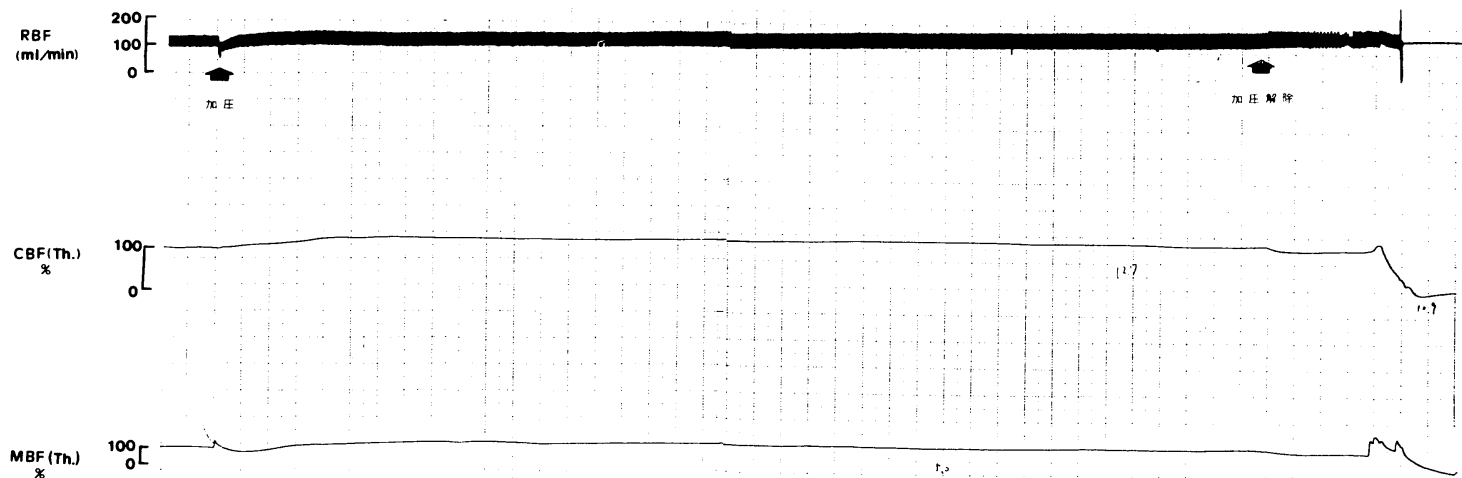

アランス法で測定した皮質血流量を $\mathrm{CBF}\left(\mathrm{CH}_{2}\right)$, 髄 質血流量を $\mathrm{MBF}\left(\mathrm{CH}_{2}\right)$, 熱電対法で測定した皮質血 流量を $\mathrm{CBF}(\mathrm{Th})$, 髄質血流量を $\mathrm{MBF}(\mathrm{Th})$ と略記 することにした。

(6) 測定手順

マニトール非負荷群では, 実験開始後, まず生食水 の入った容器への連結部を閉塞した状態で, RBF, $\mathrm{CBF}$ および $\mathrm{MBF}$ が安定するのを待ってその各々を 測定し，これを腎孟内圧上昇前値とした。次に腎孟に 插入したカテーテルと加圧容器の間を開放して, 点滴 を開始し，約 1 分前後に腎㙉内圧が上昇してそれがあ らかじめ設定された圧に達してから，30４0分保った 後に同様の測定を行い，内圧上昇後の值とした。更に 加圧を解除し, 約 1 分間で腎孟内圧が 0 になり, RBF, $\mathrm{CBF}$ ，および $\mathrm{MBF}$ が安定した時点でその各々を測定 し, 内圧上昇解除後の值とした.

マニトール負荷群に扔いては，マニトール投与前， 投与後, 左側尿管結禁 1 時間後, および結紫解除後に, その各々を同様に測定した。

（7）実験群

実験は以下の 6 群に分けて行った。

I 群：腎孟内圧を軽度 $(25 \mathrm{mmHg})$ に上昇させ，局 所血流量を水素クリアランス法で測定した群 $(\mathrm{n}=7)$.

II 群：腎盂内圧を中等度 $(50 \mathrm{mmHg})$ に上昇させ, 水素クリアランス法で測定した群 $(\mathrm{n}=5)$.

III群 : 腎孟内圧を高度 $(75 \mathrm{mmHg})$ に上昇させ, 水 素クリアランス法で測定した群 $(\mathrm{n}=8)$.

IV群：腎孟内圧を軽度 $(25 \mathrm{mmHg})$ に上昇させ局所 血流量を熱電対法で測定した群 $(\mathrm{n}=5)$.

$\mathrm{V}$ 群：腎盂内圧を高度 $(75 \mathrm{mmHg})$ に上昇させ熱電 対法で測定した群（n=5）.

VI群：マニトール負荷後に尿管を結禁および解除し た群 $(\mathrm{n}=4)$.

な报, 推計学的検討はStundent の $\mathrm{t}$ 検定により 行った.

\section{実験成績}

まずI 群, II 群, III群の腎孟内圧上昇前のそれぞれ の血流量測定結果を表 2 に示す。

ここでは腎皮質の厚さも表示しているが，測定終了 後に電極を引き抜き，皮質の厚さと電極の深さを対応 し，皮質，髄質それぞれの深さに適合しなかったもの は除外した。

表 3 は I 群, II 群, III群のそれぞれの, 腎孟内圧上 昇前, 上昇後扣よび内圧上昇解除後の RBF, BP, CBF, MBF の測定結果を示したものである。

表 4 は I 〜 III群の RBF, $\mathrm{CBF}\left(\mathrm{CH}_{2}\right), \mathrm{MBF}\left(\mathrm{CH}_{2}\right)$ の変動を, 熱電対法での測定值と比較しやすくするた め, 腎孟内压上昇前を $100 \%$ として\%表示したものであ る。以下，これにより各群に打けるそれぞれの測定值 の変動を検討すると, I 群では腎孟内圧上昇後の RBF は平均 $7.9 \%$ と有意の増加を示した $(\mathrm{p}<0.05)$. 血圧, $\mathrm{CBF}\left(\mathrm{CH}_{2}\right), \mathrm{MBF}\left(\mathrm{CH}_{2}\right)$ は有意の変化を示さず, 腎 孟内圧上昇解除後は RBF は内圧上昇前值に注腹し ていた。また，II群においては，内圧上昇後 RBF は平 均 $14.4 \%$ 上昇し $(\mathrm{p}<0.05)$ 解除後は上昇前値に医添復 して扣り, 血圧, $\mathrm{CBF}\left(\mathrm{CH}_{2}\right)$ は内圧上昇後, 解除後 共に有意の変化を示さなかった。 また, $\mathrm{MBF}\left(\mathrm{CH}_{2}\right)$ は上昇後に平均 $7.7 \%$ 上昇したが有意差はなかった。 III 群では内圧上昇後の RBF は平均 $8.2 \%$ の増加を認め $(\mathrm{p}<0.01)$ 解除後は上昇前值に戻った。 しかじ CBF 
表 2

\begin{tabular}{|c|c|c|c|c|c|c|c|c|}
\hline & 犬 No & 性 & $\begin{array}{l}\mathrm{BW} \\
(\mathrm{kg})\end{array}$ & $\begin{array}{l}\text { 皮質重量 } \\
\text { (g) }\end{array}$ & $\begin{array}{l}\text { 檤質重量 } \\
\text { (g) }\end{array}$ & $\begin{array}{l}\text { 皮質厚さ } \\
(\mathrm{mm})\end{array}$ & $\begin{array}{c}\mathrm{BP} \\
\left(\begin{array}{c}\text { mean } \\
\text { mmHg}\end{array}\right)\end{array}$ & $\begin{array}{c}\mathrm{RBF} \\
\text { (mean.ml/min) }\end{array}$ \\
\hline \multirow{4}{*}{ I } & 1 & 우 & 10 & 20 & 9 & 4.0 & 130 & 95 \\
\hline & 2 & $\hat{\delta}$ & 14 & 32 & 13 & 5.0 & 155 & 160 \\
\hline & 3 & 우 & 14 & 22 & 9 & 5.0 & 165 & 120 \\
\hline & 4 & 우 & 16 & 37 & 20 & 4.0 & 170 & 245 \\
\hline \multirow[t]{3}{*}{ 群 } & 5 & $\hat{\delta}$ & 11 & 22 & 8 & 4.5 & 130 & 122.5 \\
\hline & 6 & $\hat{\delta}$ & 12 & 20 & 8 & 4.5 & 160 & 105 \\
\hline & 7 & $\hat{o}$ & 13 & 32 & 14 & 5.0 & 130 & 185 \\
\hline \multirow{3}{*}{ II } & 8 & 우 & 13 & 22 & 8 & 5.0 & 160 & 110 \\
\hline & 9 & 우 & 13 & 22 & 8 & 5.0 & 170 & 110 \\
\hline & 10 & 우 & 10 & 20 & 8 & 4.0 & 135 & 112.5 \\
\hline \multirow[t]{4}{*}{ 群 } & 11 & $\hat{\delta}$ & 10 & 16 & 6 & 4.0 & 165 & 77.5 \\
\hline & 12 & 우 & 14 & 25 & 10 & 5.0 & 120 & 90 \\
\hline & 13 & 우 & 13 & 22 & 8 & 5.0 & 160 & 110 \\
\hline & 14 & $\hat{\delta}$ & 14 & 32 & 13 & 4.5 & 150 & 125 \\
\hline \multirow[t]{3}{*}{ III } & 15 & $\hat{\delta}$ & 10 & 16 & 6 & 4.0 & 170 & 72.5 \\
\hline & 16 & 우 & 14 & 25 & 10 & 5.0 & 125 & 90 \\
\hline & 17 & 우 & 14 & 22 & 9 & 5.0 & 165 & 80 \\
\hline \multirow[t]{4}{*}{ 群 } & 18 & 우 & 16 & 37 & 20 & 6.0 & 175 & 255 \\
\hline & 19 & $\hat{\delta}$ & 12 & 33 & 13 & 6.0 & 160 & 105 \\
\hline & 20 & $\hat{\delta}$ & 13 & 32 & 14 & 6.0 & 125 & 210 \\
\hline & $\begin{array}{l}\text { mean } \\
\pm \text { S.E. }\end{array}$ & & $\begin{array}{c}12.8 \\
\pm 0.42\end{array}$ & $\begin{array}{l}25.45 \\
\pm 1.52\end{array}$ & $\begin{array}{c}10.7 \\
\pm 0.92\end{array}$ & $\begin{array}{l}4.925 \\
\pm 0.15\end{array}$ & $\begin{array}{c}151 \\
\pm 4.13\end{array}$ & $\begin{array}{c}129 \\
\pm 12.04\end{array}$ \\
\hline
\end{tabular}

表 3

\begin{tabular}{|c|c|c|c|c|c|}
\hline & & $\begin{array}{c}\mathrm{RBF} \\
\left(\begin{array}{c}\mathrm{mean} \\
\mathrm{ml} / \mathrm{min}\end{array}\right)\end{array}$ & $\begin{array}{c}\mathrm{BP} \\
\left(\begin{array}{c}\mathrm{mean} \\
\mathrm{ml} / \mathrm{min}\end{array}\right)\end{array}$ & $\begin{array}{c}\mathrm{CBF}\left(\mathrm{H}_{2} \text { 法 }\right) \\
(\mathrm{ml} / \mathrm{min} / 100 \mathrm{~g})\end{array}$ & $\begin{array}{c}\mathrm{MBF}\left(\mathrm{H}_{2} \text { 法 }\right) \\
(\mathrm{ml} / \mathrm{min} / 100 \mathrm{~g})\end{array}$ \\
\hline \multirow{3}{*}{$\underset{(\mathrm{n}=7)}{\stackrel{\mathrm{I} \text { 群 }}{(25 \mathrm{~mm} H \mathrm{f}} \text { 上昇群) }}$} & 内圧上昇前 & $147.5 \pm 18.63$ & $148.6 \pm 6.79$ & $205.1 \pm 10.29$ & $122.3 \pm 5.69$ \\
\hline & 内圧上昇後 & $149.6 \pm 18.87$ & $151.4 \pm 5.95$ & $226.1 \pm 17.87$ & $129.8 \pm 8.35$ \\
\hline & 内圧上昇解除後 & $132.1 \pm 12.99$ & $144.2 \pm 7.46$ & $224.7 \pm 20.58$ & $120.9 \pm 7.35$ \\
\hline \multirow{3}{*}{$\underset{\substack{\mathrm{II} \text { 群 } \\
(\mathrm{n}=5)}}{(50 \mathrm{~m})}$} & 内圧上昇前 & $101.0 \pm 7.36$ & $151.0 \pm 8.86$ & $206.0 \pm 12.66$ & $97.6 \pm 9.29$ \\
\hline & 内圧上昇後 & $115.7 \pm 9.32$ & $151.0 \pm 9.92$ & $236.6 \pm 23.80$ & $105.6 \pm 11.65$ \\
\hline & 内圧上昇解除後 & $102.0 \pm 7.18$ & $153.0 \pm 8.15$ & $249.0 \pm 25.48$ & $110.2 \pm 8.30$ \\
\hline \multirow{3}{*}{$\underset{(\mathrm{n}=8)}{\substack{\text { III群 } \\
(75 \mathrm{~mm} H \text { 上昇群 })}}$} & 内圧上昇前 & $130.9 \pm 23.33$ & $153.8 \pm 6.80$ & $220.1 \pm 16.30$ & $101.1 \pm 6.61$ \\
\hline & 内圧上昇後 & $140.9 \pm 24.50$ & $153.8 \pm 7.06$ & $196.7 \pm 15.05$ & $79.7 \pm 8.06$ \\
\hline & 内圧上昇解除後 & $123.9 \pm 26.64$ & $156.4 \pm 5.64$ & $218.7 \pm 13.80$ & $104.3 \pm 7.26$ \\
\hline
\end{tabular}

$\left(\mathrm{CH}_{2}\right)$ は内圧上昇後平均 $10.4 \%$ の減少を認め $(\mathrm{p}<$ $0.01)$, 解除後は上昇前に戻った. $\mathrm{MBF}\left(\mathrm{CH}_{2}\right)$ 子内圧 上昇後平均 $21.3 \%$ の減少を認めたが $(\mathrm{p}<0.01)$ 解除後 はほぼ上昇前に復した（図 5 )。

血圧はいずれの群でも上昇直後, 解除直後に一過性 の上昇もしくは下降, 更に 2 相性の変化をみせたもの もあったが, RBF 等の測定時には注ぼ变動前値に戻っ
ていた。図 6 は腎孟内圧 $75 \mathrm{mmHg}$ 上昇群の一例で(犬 番号16)，内圧上昇前と $75 \mathrm{mmHg}$ 上昇し，約 35 分後の $\mathrm{RBF}$ 安定時の皮質と髅質に打ける水素クリアランス 曲線の変化を示したものであり，この曲線の勾配から もとれぞれの組織血流が腎孟内圧上昇と共に大きく減 少していることがわかる。

次に熱電対法による同様の実験の測定結果を表 5 に 
表 $4 （ \mathrm{I} \sim \mathrm{III}$ 群\%表示）

\begin{tabular}{|c|c|c|c|c|c|c|c|}
\hline & & \multicolumn{2}{|r|}{ 群 } & \multicolumn{2}{|r|}{ 群 } & \multicolumn{2}{|c|}{ III 群 } \\
\hline & & mean \pm S.E. & t-test & mean \pm S.E. & t-test & mean \pm S.E. & t-test \\
\hline \multirow{3}{*}{$\mathrm{RBF}$} & pre & 100 & & 100 & & 100 & \\
\hline & post & $107.9 \pm 2.26$ & $\mathrm{p}<0.05$ & $114.4 \pm 3.92$ & $\mathrm{p}<0.05$ & $108.2 \pm 2.40$ & $\mathrm{p}<0.01$ \\
\hline & rel & $100.7 \pm 1.97$ & NS & $101.6 \pm 5.54$ & NS & $101.9 \pm 3.52$ & NS \\
\hline \multirow{3}{*}{ BP } & pre & & & 100 & & 100 & \\
\hline & post & $102.2 \pm 2.12$ & NS & $99.9 \pm 1.79$ & NS & $99.9 \pm 1.46$ & NS \\
\hline & rel & $99.4 \pm 1.54$ & NS & $101.5 \pm 1.48$ & NS & $99.3 \pm 1.96$ & NS \\
\hline \multirow{3}{*}{$\underset{\left(\mathrm{CHF}_{2}\right)}{\mathrm{CBF}}$} & pre & 100 & & 100 & & 100 & \\
\hline & psot & $101.9 \pm 2.72$ & NS & $105.1 \pm 6.27$ & NS & $89.6 \pm 2.24$ & $\mathrm{p}<0.01$ \\
\hline & rel & $100.1 \pm 1.43$ & NS & $110.2 \pm 4.99$ & $\mathrm{p}<0.1$ & $96.1 \pm 3.18$ & NS \\
\hline \multirow{3}{*}{$\underset{\left(\mathrm{CH}_{2}\right)}{\mathrm{MBF}}$} & pre & 100 & & 100 & & 100 & \\
\hline & post & $106.2 \pm 5.48$ & NS & $107.7 \pm 4.18$ & NS & $78.7 \pm 5.64$ & $\mathrm{p}<0.01$ \\
\hline & rel & $98.6 \pm 3.03$ & NS & $114.8 \pm 8.17$ & NS & $101.6 \pm 5.48$ & NS \\
\hline
\end{tabular}

図 5 腎孟内圧上昇による $\mathrm{RBF}, \mathrm{CBF}\left(\mathrm{CH}_{2}\right), \mathrm{MBF}\left(\mathrm{CH}_{2}\right)$ の変動 (Mean \pm S.E.)

$\%$
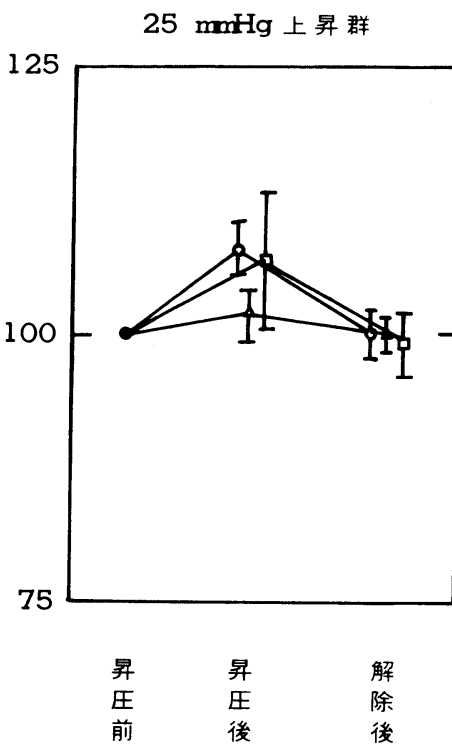

○ RBF
$50 \mathrm{mmHg}$ 上昇群

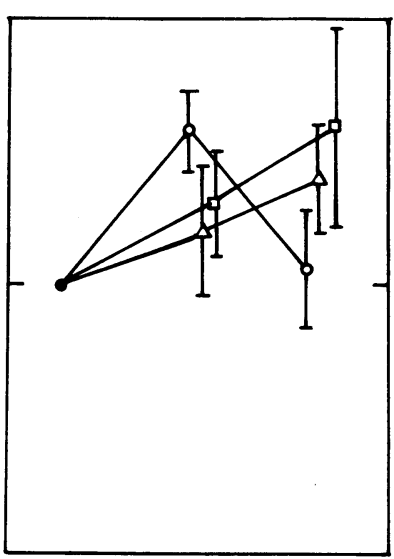

$\begin{array}{lll}\text { 杽 } & \text { 昇 } & \text { 解 } \\ \text { 压 } & \text { 压 } & \text { 除 } \\ \text { 前 } & \text { 後 } & \text { 後 }\end{array}$

$\Delta \mathrm{CBF}\left(\mathrm{CH}_{2}\right)$
$75 \mathrm{mmHg}$ 上昇群

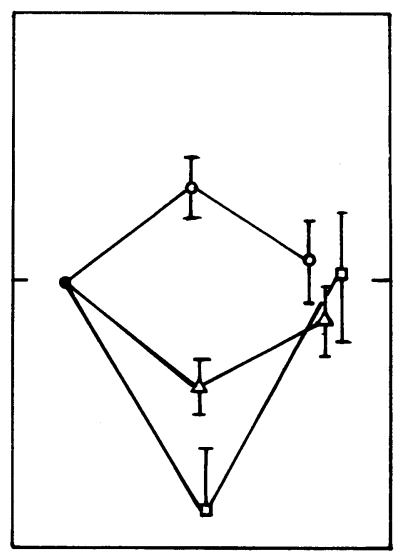

$\begin{array}{lll}\text { 昇 } & \text { 昇 } & \text { 解 } \\ \text { 圧 } & \text { E } & \text { 除 } \\ \text { 前 } & \text { 後 } & \text { 後 }\end{array}$

ㅁ $\mathrm{MBF}\left(\mathrm{CH}_{2}\right)$
示す (IV〜V 群). IV群すなわち $25 \mathrm{mmHg}$ 上昇群では, $\mathrm{RBF}$ は有意に増加し $(\mathrm{p}<0.01)$ その増加率は平均 $8.0 \%$ あった。 また，腎孟内圧上昇解除後は上昇前に ほぼ戻った。しかし皮質, 䯣質では共に平均で若干の 増加をみたが, 有意の変化ではなかった。 また，V群, すなわち $75 \mathrm{mmHg}$ 上昇群において， RBF は有意に増 加し（ $\mathrm{p}<0.05 ）$, その平均増加率は $13.3 \%$ であった。 また皮質では平均 $19.2 \%$ の有意の増加を認め $(\mathrm{p}<$
0.05）解除後はほぼ上昇前值に戻った。髄質では平均 $4.8 \%$ の増加であったが, 有意の差はなく, 解除後も有 意の変動をみなかった（図 7 ).

次にVI群の測定結果を表 $6 \sim 8$, 図 8,9 に示す。 表 6 にはマニトール注入前, 注入後, 更に左側尿管結 禁後, および結禁解除後の RBF, CBF $\left(\mathrm{CH}_{2}\right), \mathrm{MBF}$ $\left(\mathrm{CH}_{2}\right)$ の変化を示している。表 7 はこれらの増減を\% 表示に直したもので, 便宜上マニトール注入後を $100 \%$ 
表 5

\begin{tabular}{|c|c|c|c|c|}
\hline & & $\underset{\left(\begin{array}{c}\mathrm{RBF} \\
\mathrm{ml} / \mathrm{min}\end{array}\right)}{\left({ }^{2}\right.}$ & $\begin{array}{c}\mathrm{CBF}(\text { Thenmo }) \\
(\%)\end{array}$ & $\begin{array}{c}\operatorname{MBF}(\text { Thenmo }) \\
(\%)\end{array}$ \\
\hline \multirow{3}{*}{$\begin{array}{c}\text { IV群 } \\
\text { (25mmHg 上昇群) } \\
\% \text { 表示 } \\
(\mathrm{n}=5)\end{array}$} & 内圧上昇前 & $103.6 \pm 5.13$ & 100 & 100 \\
\hline & 内圧上昇後 & $\begin{array}{c}112.0 \pm 6.04 \\
(\mathrm{p}<0.01)\end{array}$ & $\underset{\text { (NS) }}{101.6 \pm 2.75}$ & $\underset{(\mathrm{NS})}{101.3 \pm 1.94}$ \\
\hline & 内圧上昇解除後 & $\underset{(\mathrm{NS})}{101.5 \pm 4.45}$ & $\underset{(\mathrm{NS})}{99.0 \pm 1.65}$ & $\underset{(\mathrm{NS})}{101.5 \pm 1.27}$ \\
\hline \multirow{3}{*}{$\begin{array}{c}\mathrm{V} \text { 群 } \\
(75 \mathrm{mmHg} \text { 上昇群 }) \\
\% \text { 姜示 } \\
(\mathrm{n}=5)\end{array}$} & 内圧上昇前 & $112.0 \pm 6.04$ & 100 & 100 \\
\hline & 内圧上昇後 & $\begin{array}{c}126.0 \pm 3.32 \\
(\mathrm{p}<0.05)\end{array}$ & $\begin{array}{c}119.22 \pm 7.31 \\
(\mathrm{p}<0.05)\end{array}$ & $\begin{array}{c}104.78 \pm 6.99 \\
(\mathrm{NS})\end{array}$ \\
\hline & 内圧上昇解除後 & $\underset{(\mathrm{NS})}{114.0 \pm 2.83}$ & $102.2 \pm 1.58$ & $\underset{(\mathrm{NS})}{97.96 \pm 4.23}$ \\
\hline
\end{tabular}

図 6 腎孟内圧上昇前後の水素クリアランス曲線

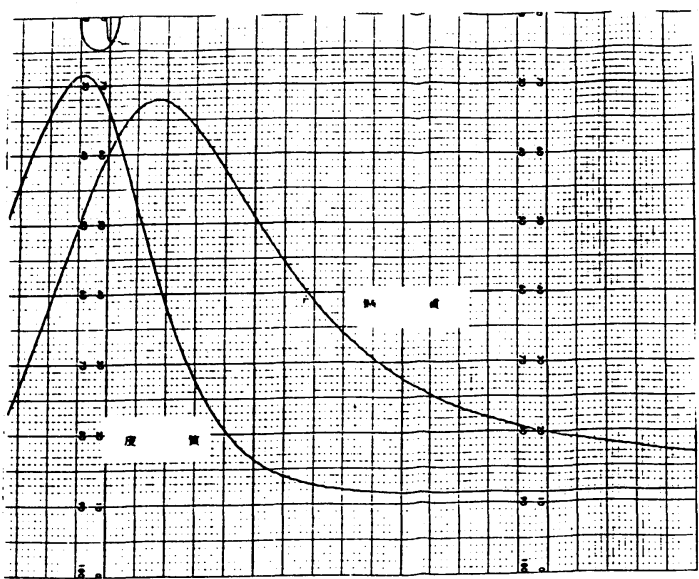

としている。

これによるとマニトール注入後は, 前に比べて RBF が平均 $39.0 \%$ の増加 $(\mathrm{p}<0.05)$ 皮質が $21.4 \%$ の増加 $(\mathrm{p}<0.05)$ 髄質が $26.2 \%$ の増加 $(\mathrm{p}<0.01)$ と, 測定し た全ての著明な増加をみた。

次にマニトール注入後と尿管結禁後を比べると, $\mathrm{RBF}$ は平均 $21.2 \%$ の減少 $(\mathrm{p}<0.05) \mathrm{CBF}\left(\mathrm{CH}_{2}\right)$ は $27.5 \%$ の減少 $(\mathrm{p}<0.05), \mathrm{MBF}\left(\mathrm{CH}_{2}\right)$ は $34 \%$ の減少 $(\mathrm{p}<0.01)$ であった. 更に尿管結禁の解除後について みると, マニトール注入後の值に対してはRBF が平 均 $31.1 \%$ の減少 $(\mathrm{p}<0.002), \mathrm{CBF}\left(\mathrm{CH}_{2}\right)$ は $34.1 \%$ の 減少 $(\mathrm{p}<0.01) \mathrm{MBF}\left(\mathrm{CH}_{2}\right)$ は28.15\%の減少であっ た。ただし $\mathrm{MBF}\left(\mathrm{CH}_{2}\right)$ のみは有意の変化ではなかっ た。 また，尿管結紮後とその解除後とを比較したが， $\mathrm{RBF}, \mathrm{CBF}\left(\mathrm{CH}_{2}\right), \mathrm{MBF}\left(\mathrm{CH}_{2}\right)$ のそれぞれの血流量 に有意の変化はなかった。

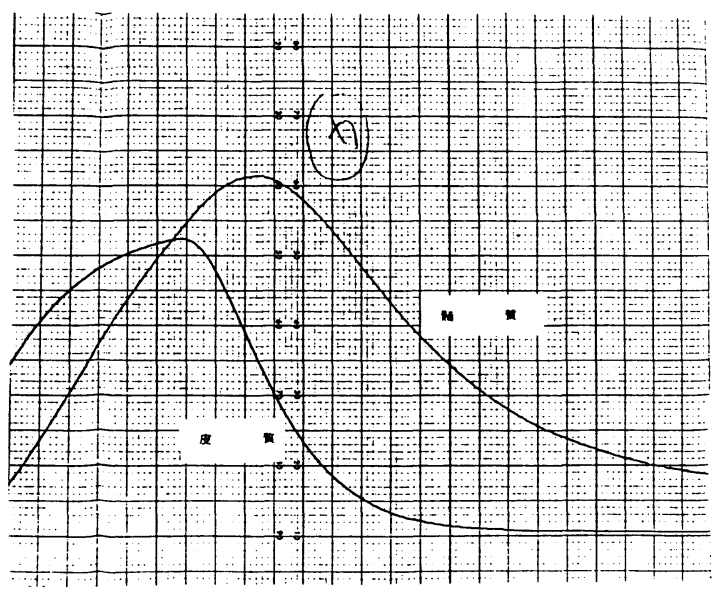

表 8 は水素クリアランス法と同時に測定した熱電対 法による腎皮質および䯣質の組織血流量の変化であ る。これによるとマニトール注入後は注入前に比べ， $\mathrm{CBF}(\mathrm{Th})$ で平均 $33.85 \%(\mathrm{p}<0.002), \mathrm{MBF}(\mathrm{Th})$ で平均 $25.2 \%(\mathrm{p}<0.002)$ の増加をみた。尿管結禁後 をマニトール注入後と比較してみると, CBF (Th) で $39.3 \%(\mathrm{p}<0.002), \mathrm{MBF}(\mathrm{Th})$ で30.0\% ( $<<0.05)$ の減少をみた。更に，尿管結禁の解除後をマニトール 注入後の值と比較してみると, CBF（Th）では平均 43.9\%（p<0.002）の減少であったが, MBF（Th）で は平均 $13.7 \%$ の減少であり有意の差はなかった。 また， 尿管結紮後と結紮解除後を比較すると, CBF (Th) で はマニトール注入後を $100 \%$ として, 約 $4 \%$ の減少, MBF (Th)では16.3\%の増加をみたが，いずれも有意 の変化ではなかった。 
表 6 （VI群，マニトール負荷群）

\begin{tabular}{|c|c|c|c|c|c|}
\hline & & $\begin{array}{c}\mathrm{RBF} \\
\left(\begin{array}{c}\mathrm{mean} \\
\mathrm{ml} / \mathrm{min}\end{array}\right)\end{array}$ & $\mathrm{BP}\left(\mathrm{mean}_{\mathrm{ml} / \mathrm{min}}\right)$ & $\underset{(\mathrm{ml} / \mathrm{min} / 100 \mathrm{~g})}{\mathrm{CBF}\left(\mathrm{H}_{2} \text { 法 }\right)}$ & $\begin{array}{l}\mathrm{MBF}\left(\mathrm{H}_{2} \text { 法 }\right) \\
(\mathrm{ml} / \mathrm{min} / 100 \mathrm{~g})\end{array}$ \\
\hline \multirow[t]{4}{*}{$\begin{array}{c}\text { VI群 } \\
(\mathrm{n}=4)\end{array}$} & $\begin{array}{c}\text { マ三トール } \\
\text { 負荷前 }\end{array}$ & $120.0 \pm 19.04$ & $111.3 \pm 14.20$ & $224.6 \pm 9.45$ & $84.5 \pm 3.83$ \\
\hline & $\begin{array}{l}\text { マ三トール } \\
\text { 負荷後 }\end{array}$ & $158.8 \pm 9.44$ & $135.0 \pm 15.41$ & $252.6 \pm 12.82$ & $107.1 \pm 8.18$ \\
\hline & 尿管結禁後 & $120.0 \pm 6.12$ & $127.5 \pm 5.20$ & $197.4 \pm 18.02$ & $71.2 \pm 9.30$ \\
\hline & 結禁解除後 & $110.0 \pm 10.61$ & $108.8 \pm 8.75$ & $179.4 \pm 23.09$ & $74.8 \pm 14.82$ \\
\hline
\end{tabular}

図 7 腎昷内圧上昇による $\mathrm{CBF}(\mathrm{Th}), \mathrm{MBF}(\mathrm{Th})$ の 変動 (Mean士S.E.)
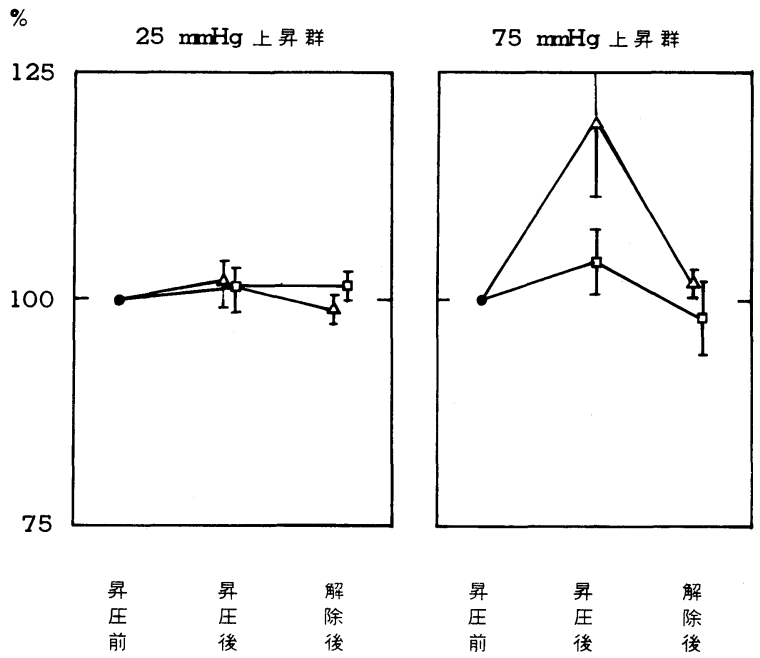

$\triangle \mathrm{CBF}(\mathrm{Th})$

$\square \mathrm{MBF}(\mathrm{Th})$

表 7 (VI群, マニトール負荷群一水素クリアランス 法一％表示）

\begin{tabular}{c|c|c|c|c}
\hline & & $\begin{array}{c}\mathrm{RBF} \\
(\%)\end{array}$ & $\begin{array}{c}\mathrm{CBF}\left(\mathrm{H}_{2} \text { 法 }\right) \\
(\%)\end{array}$ & $\begin{array}{c}\mathrm{MBF}\left(\mathrm{H}_{2} \text { 法 }\right) \\
(\%)\end{array}$ \\
\hline $\begin{array}{c}\text { VI群 } \\
(\mathrm{n}=4)\end{array}$ & $\begin{array}{c}\text { マ=トール } \\
\text { 負荷前 }\end{array}$ & $75.3 \pm 7.15$ & $83.3 \pm 4.49$ & $79.45 \pm 2.45$ \\
\cline { 2 - 5 } & $\begin{array}{c}\text { マ } \\
\text { 負荷後 }\end{array}$ & $\begin{array}{c}100 \\
(\mathrm{p}<0.05)\end{array}$ & $\begin{array}{c}100 \\
(\mathrm{p}<0.05)\end{array}$ & $\begin{array}{c}100 \\
(\mathrm{p}<0.01)\end{array}$ \\
\cline { 2 - 5 } & 氺管結禁後 & $\begin{array}{c}78.75 \pm 6.71 \\
(\mathrm{p}<0.05)\end{array}$ & $\begin{array}{c}72.5 \pm 4.68 \\
(\mathrm{p}<0.05)\end{array}$ & $\begin{array}{c}66.05 \pm 7.42 \\
(\mathrm{p}<0.01)\end{array}$ \\
\cline { 2 - 5 } & 結禁解除後 & $\begin{array}{c}68.9 \pm 3.09 \\
(\mathrm{p}<0.002)\end{array}$ & $\begin{array}{c}65.9 \pm 7.46 \\
(\mathrm{p}<0.01)\end{array}$ & $\begin{array}{c}71.9 \pm 17.79 \\
(\mathrm{NS})\end{array}$ \\
\hline
\end{tabular}

（マニトール負荷後を100としている）

\section{考按}

腎盂内圧の上昇が腎循環動態に大きく影響を与える ことは古くから知られて拈り, 例壳ばLevy ${ }^{16)}$ は尿
表 8 （VI群，マニトール負荷群一熱電対法一\%表示）

\begin{tabular}{c|c|c|c}
\hline & & CBF(Thermo) & MBF(Thermo) \\
\hline $\begin{array}{c}\text { VI群 } \\
(\mathrm{n}=4)\end{array}$ & $\begin{array}{c}\text { マニトール } \\
\text { 負荷前 }\end{array}$ & $75.5 \pm 2.05$ & $80.7 \pm 5.01$ \\
\cline { 2 - 4 } & $\begin{array}{c}\text { マ=トール } \\
\text { 負荷後 }\end{array}$ & $\begin{array}{c}100 \\
(\mathrm{p}<0.002)\end{array}$ & $\begin{array}{c}100 \\
(\mathrm{p}<0.002)\end{array}$ \\
\cline { 2 - 4 } & 尿管結禁後 & $\begin{array}{c}60.7 \pm 4.74 \\
(\mathrm{p}<0.002)\end{array}$ & $\begin{array}{c}70.0 \pm 9.53 \\
(\mathrm{p}<0.05)\end{array}$ \\
\cline { 2 - 4 } & 結禁解除後 & $\begin{array}{c}56.1 \pm 4.51 \\
(\mathrm{p}<0.002)\end{array}$ & $\begin{array}{c}86.3 \pm 15.63 \\
(\mathrm{NS})\end{array}$ \\
\hline
\end{tabular}

図 8 マンニトール負荷後の $\mathrm{RBF}, \mathrm{CBF}\left(\mathrm{H}_{2}\right), \mathrm{MBF}$ $\left(\mathrm{H}_{2}\right)$ の変動 $($ Mean \pm S.E. $)$

$\%$

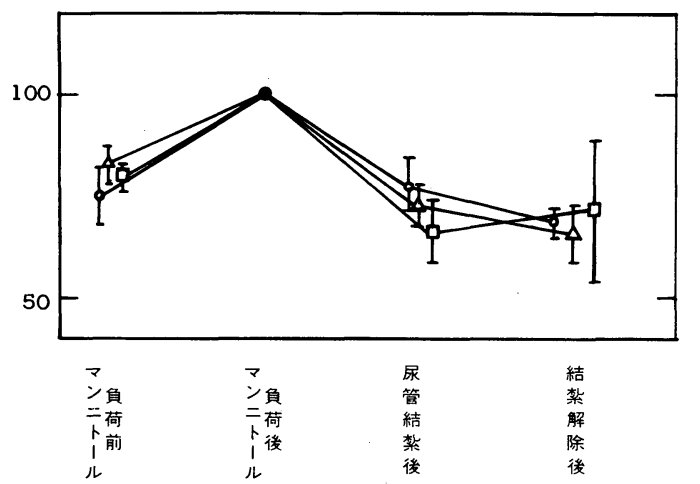

$$
\text { - } \mathrm{RBF} \quad \triangle \mathrm{CBF}\left(\mathrm{CH}_{2}\right) \quad \square \mathrm{MBF}\left(\mathrm{CH}_{2}\right)
$$

路内圧の上昇は最終的に腎血流量と酸素消費量の低下 をもたらすとしており，Vaughan ら ${ }^{17)}$ も一側尿管閉塞 後 $2 \sim 3$ 週間にわたりその腎孟内圧, 腎血流量および 対側の腎血流量などを詳細に実験して，同様の結論を 得ているが，なぜ腎血流量が减少してしまうのかは, まだ不明な点が多い。

ところが麻酔犬に招いて尿管閉塞後 $1 \sim 2$ 時間程度 
図 9 マンニトール負荷後の CBF (Th) MBF (Th)

の変動 (Mean \pm S.E.)

$\%$

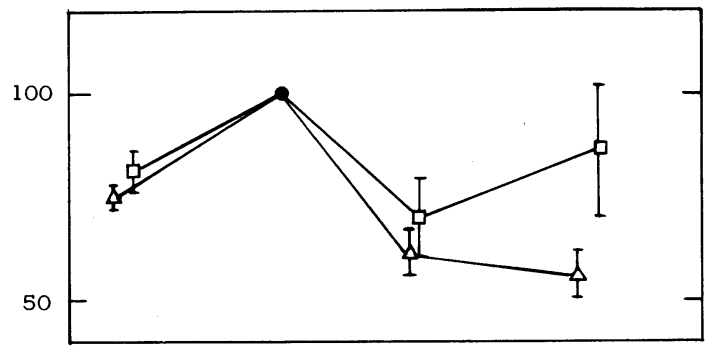

$\begin{array}{llll}\text { マ } & \text { マ負 } & \text { 尿 } & \text { 結 } \\ \text { ン負 } & \text { ン荷 } & \text { 管 } & \text { 慗 } \\ \text { 荷 } & \text { 後 } & \text { 結 } & \text { 解 } \\ \text { 1前 } & \text { 前 } & \text { 紮 } & \text { 除 } \\ \text { ル } & \text { ル } & \text { 後 } & \text { 後 }\end{array}$

$\triangle \mathrm{CBF}(\mathrm{Th})$

$\square \mathrm{MBF}(\mathrm{Th})$

の急性期には腎盎内圧の上昇に伴い，一過性の腎血流 量増加が認められるとされ37718), 無麻酔犬でも同様に 一過性の腎血流増加を認めたとの報告がある ${ }^{19)}$. この 急性期の腎血流量増加については諸説が有るが，例壳 ば腎静脈反射によって伝達された血管拡張によるとの 説や ${ }^{18)}$, 腎間質圧の上昇, 腎静脈抵抗の増加が血管壁内 外圧差の低下をもたらし，細動脈壁の張力を低下させ ることによる ${ }^{20}$ などの腎の自己調節機能によるとする もの, またその mediater として,レニンあるいはプロ スタグランジンを関連づける論文など，多くの報告が みられる4)721).

しかし腎血内圧上昇時の腎の血流増加が，実際には 腎のどの部分の流量が増えたことによるかは依然とし て不明な部分が多いし，その状態に拈ける尿の再吸収， 濃縮との関連が注目されるところである。

ここで腎循環につき従来より述べられていることに つき改めて検討を加えてみると，腎動脈は分岐しつつ 腎内に入り皮質外層部では各輸入動脈が分枝し，系球 体毛細血管，輸出細動脈，尿細管周囲毛細血管，小葉 間静脈，弓状静脈となり，更に葉間静脈から腎静脈を 経て下大静脈に入るわけであるが，皮質深層部すなわ ち傍髄質部に括いては輸入細動脈より糸球体毛細血管 を形成するものの他に，輸入細動脈より直接輸出細動 脈を経て毛細血管網を形成するものも認められるのが 特徵である。

一方, 髄質血行に関与する血管は二系統に分けられ，
その一つは皮質型糸球体からの輸出血管が尿細管周囲 の毛細血管網を形成しつつ髄質に移行するものであ り, ら一つは傍髄質糸球体より由来するV asa Rectaでありこれが髄質血管の主体をなすとされてい $ろ^{22)}$.

もら一つの腎循環の特徵は shunt の存在であり, こ れは機能的にも重要な役割を果しているといわれ る23). shuntについては従来より様々な説があり 24)25), 例えば Munkácsi ら ${ }^{24)}$ はレジンを腎動脈に注入し，各 種条件下に拈ける腎内血管の鋳型を作り，その腎皮質 内での存在を証明し, Takazakura ら ${ }^{25)}$ は Microangiogramなどを用い，加齢や病的状態と輸入，輸出血 管の直接交通路の形成につき検討している。また古く は, Barrie らが弓状動脈より弓状静脈に直接短絡する 交通路について述べており ${ }^{26)}$ ，これは墨汁注入法によ りラセン状の小動脈として確認されている ${ }^{27)}$.

これらの短絡は概ね 4 群に大別されて和り ${ }^{23)}$ ，(i) 糸球体血管極付近のもの, (ii) 皮質内動脈から毛細管 へのもの,(iii) 皮髄境界付近の動静脈を結びつけるも の，(iv）被膜に直行するもの，などがそれである。ま た竹内らは輸入, 輸出動脈間の shunt を制御する機構 として, その間に平滑筋による sphincter の存在を仮 定して扣り, 輸入, 輸出動脈を連続切片で追及し, こ れを裏づけている27).

これらの交通路の開閉により腎動脈血の一部が皮質 を通過せずに弓状静脈に注入し, 更に腎静脈内圧上昇 と血流増加をもたらし, 結果的に髄質の血行もしくは 静脈性 Vasa Recta 血行の停帯につながる.つまりこ れらの交通路は皮質，髄質それぞれの血流状態を制御 し特に髄質 Vasa Recta が Countercurrent multiplying system として働いているという説が普遍化して いることから，腎機能自体に大きな役割を果している と考壳られる.

次に, 従来よりなされている諸種の組織血流量測定 法について，本実験に扣ける測定法も含めて，若干の 検討を加えてみる、私が調べた範囲では，従来より腎 の組織血流量を測定するのに用いた方法としては, radioactive microsphere 法 (MS 法) ${ }^{1) 6) 28) 29)}$, Indocyanine green 平均通過時間測定法 ${ }^{230)}$, PAH 除去 法 ${ }^{3)}{ }^{31)},{ }^{85} \mathrm{Kr}$ 洗い流し法 ${ }^{4)},{ }^{86} \mathrm{Rb}$ 取込み法 ${ }^{5)},{ }^{131} \mathrm{I}$ 標識 ルブミン取込み法8), 水素クリアランス法9), 交叉熱電 対法 ${ }^{14)},{ }^{133} \mathrm{Xe}$ 洗い流し法 ${ }^{32) 33)},{ }^{125}$ I-Iodoantipyrine 取 りこみ法 ${ }^{34)}$, 熱クリアランス法35), などがあった。これ らを大別すると，（i） PAH 除去法(FPAH)，（ii）洗い 
流し法，(iii）MS 法，(iv）熱電対法，に分類できると 考えられるが，これらはそれぞれ長所，欠点が指摘さ れて打り，例觉ば ЕРAHは䯣質については $\mathrm{MBF}=$ $\mathrm{RBF} \times(1-\mathrm{EPAH})$ から求めており，あくまでも間接的 に得られた值にすぎないとされている.また，MS 法に ついては皮質内での数層（多くの論文は 4 層に分けて いる）ので相対的な増減の比較のみで，局所血流量の 絶対値では求められず，その原理上髄質血流は測定で きない．また，不活性ガス洗い流し法や熱クリアラン ス法は原理的には似かよったものであり，色素希釈法 は非拡散性物質を標識として用いているが，それらの 方法によって得られた皮質，䯣質各々の血流量は表 13 でみるよらに，一致していない場合もかなり見受けら れる。更に熱電対法についてみると，本法は二点間の 熱伝導度が，その間の血流と比例するという原理から みて, 洗い流し法, MS 法などは大きく異っており電対 間のいわゆる non-nutrient flow も合わせて測定され る. しかし連続的に測定される長所とともに, 絶対値 で表わせないという欠点も有している。

次に私が水素クリアランス法执よび熱電対法を用い て測定した腎の局所血流量の值について検討を加兄 る。まず腎の重量であるが，体重，性別に応じて重量 差が認められるが，皮質の全腎に対する重量比は $64.9 \%$ 73.3\%と，山本ら ${ }^{36)}$ の MS 法による血流測定 の際の腎皮質の割合 $78.4 \%$ に比べやや小さい值であっ た。しかし概㸚皮質の全腎重量に対する割合は約 $70 \%$ とみてよいようである。

腎孟内圧上昇前すなわちコントロールとしての腎血 流量は $228 \sim 456 \mathrm{ml} / \mathrm{min} / 100 \mathrm{~g}$ で, 平均 $347.6 \mathrm{ml} / \mathrm{min} /$

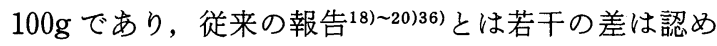
られるが，葟汇似かよった值といえる，水素クリアラ ンス法によった皮質扣よび髄質血流量についてみてみ ると，まず皮質についてであるが，皮質に扔いては $157.5 \sim 288.8 \mathrm{ml} / \mathrm{min} / 100 \mathrm{~g}$ で, 平均 $216.3 \mathrm{ml} / \mathrm{min}$ とや や数值に幅が認められるものの Aukland らの報告と

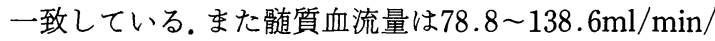
$100 \mathrm{~g}$ 平均 $107.7 \mathrm{ml} / \mathrm{min} / 100 \mathrm{~g}$ であった。髄質血流量に ついてはAuklandらは触れていないが， Hamburger ${ }^{37)}$ らよる諸家の報告のまとめと比較し てみると, thermodilution法よりは小さい値であ り, ${ }^{131} \mathrm{I}$ アルブミン拡散法や PAH 除去法より大で, ${ }^{85}$ K Washout 法と似た値をとっている.

次に腎盘内圧上昇後の $\mathrm{RBF}$ の変動について検討し てみる。本実験の目的の一つは従来述べられている腎 孟内圧上昇の急性期の $\mathrm{RBF}$ 増加が，腎孟内圧上昇の 程度とどのような関係にあるかを調べることであっ た。しかし水素クリアランス法によるI III 群をみる と, $25 \mathrm{mmHg}$ 上昇群, $50 \mathrm{mmHg}$ 上昇群, $75 \mathrm{mmHg}$ 上 昇群ともにそれぞれの有意の $\mathrm{RBF}$ 増加を示してはい るものの, その增加の程度は $25 \mathrm{mmHg}$ 群で平均 $7.9 \% 50 \mathrm{mmHg}$ 群で平均 $14.4 \%, 75 \mathrm{mmHg}$ 群で $8.2 \%$ であり，腎孟内圧上昇の程度と腎血流量の増加の間に 明らかな相関は認められなかった。また熱電対法測定 群に颃いても，IV群，V群の二群間の增加に有意の差 は認められなかった. 更に血圧の変化についてみると, 私の行った全ての実験群で有意の変動を認めなかっ た.これはV Vaughan らの測定結果7) とは相反するすの であるが，このような違いが出たのは腎孟内圧を上昇

表 9 皮質拝よび髄質血流量(Hamburger) ${ }^{377}$

\begin{tabular}{|c|c|c|c|c|c|c|c|c|}
\hline 方 法 & & $\begin{array}{c}{ }^{131} \mathrm{I} \\
\text { アルブミン } \\
\text { 拡散法 }\end{array}$ & $\begin{array}{l}\text { PAH } \\
\text { 除去法 }\end{array}$ & $\begin{array}{l}\text { 血素稀釈法 } \\
\text { (局所測定) }\end{array}$ & 熱 稀 & 橎 法 & $\begin{array}{l}\text { 色素稀橎法 } \\
\text { (静脈で } \\
\text { 測定) }\end{array}$ & $\begin{array}{c}{ }^{85} \mathrm{Kr} \text { 洗い } \\
\text { 流し法 }\end{array}$ \\
\hline 研究者 & & Lilienfield & Reubi & Kramer & \multicolumn{2}{|c|}{ Sadler } & Reubi & Thorburn \\
\hline 動物種 & & 17 & E & 17 & 1 ₹ & t & E & 17 \\
\hline $\begin{array}{c}\text { 血流量 } \\
(\mathrm{ml} / \mathrm{min} / \\
100 \mathrm{~g})\end{array}$ & $\begin{array}{l}\text { 皮質 } \\
\text { 䯣質外層 } \\
\text { 䯣質内層 } \\
\end{array}$ & 24 & & $\left\{\begin{array}{l}440 \\
21.8\end{array}\right.$ & $\begin{array}{r}255-758 \\
135-228 \\
53-61 \\
\end{array}$ & $\begin{array}{l}460-916 \\
150-225\end{array}$ & & $\begin{array}{r}417-534 \\
95-165 \\
12-28 \\
\end{array}$ \\
\hline $\begin{array}{c}\text { 血 流 } \\
(\%) \\
\end{array}$ & $\begin{array}{l}\text { 皮質 } \\
\text { 䯣質外層 } \\
\text { 䯣質内層 }\end{array}$ & & $\begin{array}{r}85-95 \\
5-15\end{array}$ & & & & $\begin{array}{r}80-93 \\
7-20\end{array}$ & \\
\hline $\begin{array}{c}\text { 標識の } \\
\text { 平均通過 } \\
\text { 時間 }(\mathrm{sec})\end{array}$ & $\begin{array}{l}\text { 皮 質 } \\
\text { 䯣質外層 } \\
\text { 䯣質内層 }\end{array}$ & & & $\begin{array}{r}2.5 \\
27.7\end{array}$ & & & $\begin{array}{r}5-11 \\
19-25\end{array}$ & \\
\hline
\end{tabular}


させる方法が異なりそれに伴ら代償機転の程度が相違 することに基づくと思われる。例兄ば Gilmoreら は ${ }^{38)}$, マニトール利尿下にかなり急激な腎孟内圧の上 昇挹よび下降下に扣ける RBF, 血圧の変動をみている が，血圧に関しては著明な変化をみていない，やはり 腎盂内圧上昇の方法の違いからであろらと考学られ る.

$\mathrm{CBF}$ と $\mathrm{MBF}$ の変化についてみると, 水素クリアラ ンス法で測定した場合, 腎孟内压が $2.5 \mathrm{mmHg}$ 和よび $50 \mathrm{mmHg}$ に上昇してもいずれ組織血流量としては有 意の変化をみていない。しかし $75 \mathrm{mmHg}$ に上昇する と，明らかに CBF, MBF 共にそれぞれ平均 $10.4 \%$, $21.3 \%$ の有意の低下をみせた。乙かし熱電対法で測定 したものは, $25 \mathrm{mmHg}$ 群では皮質, 髄質共に有意の変 化は認められなかったが, $75 \mathrm{mmHg}$ 上昇群で, 䯣質で は有意の変化は認められなかったものの, 皮質では平 均 $19.2 \%$ と有意の増加をみた。

この結果をどのように考えたら良いのであろらか。

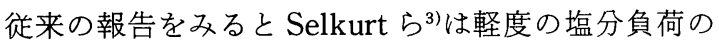
条件で一側尿管結禁後に RBF の増加と $\mathrm{EPAH}$ 低下を みたため, 髄質血液の増加を推定しており, それには 動静脈短絡の開放が関わっているとみるのが合理的で あるとしている。 また Suki ら²)は水素クリアランス法 で腎皮質外層血流量を同様な条件下で測定し, その低 下と RBF の増加から, 髄質血流量の増加を推定し, 前 説を支持している。しかし MS 法を用いた Bays ら ${ }^{1)}$, Abe ${ }^{6)}$ は同様の条件で RBF の上昇と皮質第三層の 血流の増加拉よび第一層の減少を認め, 皮質の外層は 自動調節機能が乏しいと推定している。また Hárzing $ら^{5)}$ は急性尿管閉塞時の $\mathrm{RBF}{ }^{86} \mathrm{Rb}$ 取り込み法によ る $\mathrm{RBF}\left(\mathrm{RBF}-{ }^{86} \mathrm{Rb}\right)$ を比較し, その間の解離より ${ }^{86} \mathrm{Rb}$ の血流はいわゆる nutrient flow であり尿管閉塞の際 $\mathrm{A}-\mathrm{V}$ shunt が開放されるためであると仮説立ててい る.

私の実験結果は皮質においての組織血流量について

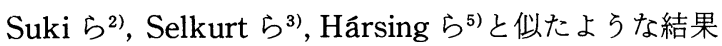
となって招り，それが前述した腎内の A-V shunt のい ずれの部分かは断定できないが，少くとも皮質におい ては水素のクリアには関らず, 熱電対の加温側と対応 点の間の伝導速度を変化させるような血行がやはり大 きく関与していると考学ざるを得ず，それが直接静脈 側に流入し, 前に述べた機序により静脈性 Vase Recta の血行の停滞をもたらすと思われる。ただし，75 $\mathrm{mmHg}$ 上昇群の熱電対法による血流が, 皮質において
は増加したのに対し，䯣質に抢いては有意の変化を示 していない。この理由として, 腎孟内圧が $75 \mathrm{mmHg}$ 禾 で上昇すると，腎孟がきわめて大きく拡張し，髄質自 体が組織圧により変形してしまい, そのため電極の位 置が多少移動する可能性も否定できず，このような結 果をもたらしたとも考学られる。いずれにしても，私 の実験結果では，このような急激な腎孟内圧上昇によ り, 従来よりたびたび述べられてきた。例兄ば急性系 球体腎炎の時の血行動態32) と似たような機序が働き， 糸球体を通過しないで腎静脈に還るいわば血行の空ま わり現象ともいうべきものが異った二つの血流測定に より示唆された。腎骵質では皮質との境界より乳頭先 端部に向って高まる浸透圧勾配が存在し，この勾配が 高張尿産生時には著明になり, 髄質血流量が増加すれ ばこの系の効率が落ちて渗透圧勾配の減少と, 尿渗透 圧の低下をもたらすとされている39)，髄質を流れる血 流量は皮質に比べてきわめて少く，その少いことが渗 透圧勾配の維持に役立ち，特にVasa Recta が counter current multiplying system として働くこと は以前から述べられていると抢りであるが2), 腎再内 圧上昇後の髄質血流量の変動や濃縮力の変化について は，いまだに一定の見解は得られていない，私の実験 では先に述べたような機序により静脈性 Vasa Recta 血行の停滞がもたらされていると予想される.

本実験のような, いわば急性腎孟内圧上昇ともいら べき状態での GFR，尿細管分泌などについては，現在 まであまりはっきりした見解はないが，これに近い状 態すなわち尿管を結禁し，その尿量に応じて腎孟内圧 が上昇する程度の急性腎孟内圧上昇時には次のような 現象が起っているとされている，すなわち腎血流量は 先に述べたような機序に従い，一過性に増加するが， GFR は低下しても完全に 0 とはならず, nephronから の尿流入と，いわゆる腎，腎孟逆流現象を呈し，腎と 腎孟相互の間に物質の移動が行われているとされてい る ${ }^{40)}$. なた, 尿細管の能動的分泌作用も働いているとさ れて括り ${ }^{41)}$, 本実験のような急性実験に括いても, inulin, $\mathrm{PAH}$ などの投与後の閉塞腎孟内尿中での定量 により検討が必要と思われる。

腎孟内圧上昇時の血流増加については，液性因子の 関与についても報告があり, 例党ばAllen ら ${ }^{21)}$ は PG の関与を指摘し、インドメサシンの前投与により, 腎 孟内圧上昇時の血流増加を認めなかったと報告してお り，今後更に検討を加えたいところである.

次にマニトールを負荷した状態における局所血流量 
の変化について検討を加える.

従来より種々の利尿剂の腎血行に対する影響につい てはいろいろな実験がなされ，特に furosemideや ethacrynic acid については例えば Birtch ら ${ }^{42)}$, Stein $ら^{28)}, \mathrm{McNay} ら^{29)}$ な゙の報告があり，後二者はMS 法 にて測定しているため䯣質の血流分布については触れ 得ず，Furosemide 投与下では皮質の第二層と第三層 の血流増加が RBF の増加をもたらすとしている。こ れに対し，Birtch らは傍髄質扣よび髄質外層血流の減 少を ${ }^{85} \mathrm{Kr}$ 法に認め, これが遠位尿細管での $\mathrm{Na}$ 再吸収 を抑制していると推定した。これらの報告では測定法 や条件により, 結論にかなりの相異が認められ, 今後 も議論の余地の多いところと思われる。

一方，マニトール負荷時の腎血行動態についての報

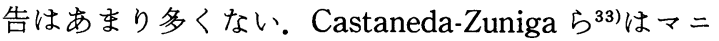
トールが RBF を増加させ， RPF と CPAH から間接的 に算定されたいわゆる non cortical plasma flow が, 単なる生食水を点滴静注した犬の群に比較して, 増加 した程度が有意に大さいと述べている。 また, McNay $ら^{29)}$, Velasquez $5^{30)}$ も, 直接的に測定したものではな いが，やはり髄質血流の増加を予測している。

私が測定した結果では，マニトールを負荷する前後 において $\mathrm{RBF}$ と，水素クリアランス法による $\mathrm{CBF}$ $\left(\mathrm{CBF}\left(\mathrm{CH}_{2}\right)\right)$ ，拈よび $\mathrm{MBF}\left(\mathrm{MBF}\left(\mathrm{CH}_{2}\right)\right)$ のいず れもがマニトール負荷前より負荷後で有意の増加を示 していた。また，熱電対法による皮質と髄質に打ける 組織血流量 (CBF (Th) および MBF (Th)) もやはり 同様の変化を示した。 これは, マニトールの作用機序, すなわち尿細管内での浸透圧の上昇が水分の再吸収を 抑制するとともに, 髄質血流の増加により浸透圧勾配 を減少させ，利尿効率を更に良くしているとも考学ら れ，Thurau ら ${ }^{43)}$ のいわる wash out theoryを更に 強く裏づけるものと考兄られる。 また皮質血流の変化 については Pilkington ら ${ }^{31)}$ が EPAHにより，髄質とと もに皮質での血流増加を認めているが，その意義につ いては不明確な部分が多い。また MS 法による MacNay らの実験によれば29)あまり有意の変動を示さず, 皮質血流の変化自体が，マニトールの利尿作用にあま り関与していないとされているょうである。私の実験 では, 皮質血流は水素クリアランス法, 熱電対法のそ れぞれに扔いて有意に増加して扣り，従来の他法によ る測定結果とほぼ同様の結果が得られた。

また，マニトールを負荷した状態で尿管を結禁する と, 腎盎内圧は速やかに上昇し, $75 \mathrm{mmHg} \sim 100 \mathrm{mmHg}$
程度となり, 本実験の前半部の $75 \mathrm{mmHg}$ 上昇群と同じ よらな条件を作り出すことができたことは前述したと おりである.しかしながらこの場合は, 明らかに $\mathrm{I} \sim \mathrm{V}$ 群のマニトール非負荷群に比べて異った血流変動がも たらされている。すなわち腎㙉内圧上昇時の CBF $\left(\mathrm{CH}_{2}\right), \mathrm{MBF}\left(\mathrm{CH}_{2}\right), \mathrm{CBF}(\mathrm{Th}), \mathrm{MBF}(\mathrm{Th})$ の低下 が認められている。

この現象についてくわしく検討しているような報告 はあまり見当らないが，マニトールのような再吸収さ れない溶質が既に尿細管内に充たされている状態で急 激な腎血内圧上昇がもたらされると, Dibona ${ }^{44)}$ が述べ るように遠位尿細管の $\mathrm{Na}^{+}$濃度が低下し，事実上の $\mathrm{Na}^{+}$の排泄停止がもたらされ，腎静脈に括けるレニン 活性が上昇すると考兄られる，その際レニン基質と反 応し, 最終的にはアンギオテンシン II が生じ ${ }^{45)}$, 輸出入 動脈の収縮と, GFR の減少に至ると考兄られる. 事実, 私の実験では $\mathrm{RBF}, \mathrm{CBF}\left(\mathrm{CH}_{2}\right)$ ，および $\mathrm{CBF}(\mathrm{Th})$ が著明に低下して扔り，その機序としては上に述べた レニンーアンギオテンシン系 (RAS) が多少なりとも関 与していると考光られる。しかし $\mathrm{MBF}\left(\mathrm{CH}_{2}\right), \mathrm{MBF}$ （Th）の低下については, Carlson ${ }^{4)}$ 述べるように平 滑筋のトーヌスの低下しているところに，急激な腎孟 内圧上昇による髄質の組織圧上昇が䯣質血管を圧迫し 受動的な血流低下をもたらすのか，もしくは浸透圧勾 配維持のための合目的な能動的作用によるかは，今回 の検討からは明らかではない，また，尿管結禁解除後 の血流は，マニトール非負荷群に扣いては概ね尿管結 禁前値に復していたのに対し，マニトール負荷群では 尿管結禁前值には戻らず，むしろ更に減少しているも のも認められた。その原因はやはりマニトール負荷に よる血管壁トーヌスの低下が，閉塞解除による腎孟内 圧の減弱に対して自己調節機能が反応しなくなってい るためとも考えられる。いずれにしても浸透圧利尿剤 を負荷した状態で急激に尿管結禁を行うことは, 結禁 腎に対して回復不能と思われる程のダメージを与えて いることは想像に難くない。

\section{結 論}

雑種成犬を用いて，人為的に一側の腎孟内圧を急速 に上昇させ，その際の同側腎動脈血流量を測定し，同 時に二つの異なった原理に基づいている測定法，すな わち水素クリアランス法および熱電対法により，腎の 皮質, 髄質の組織血流量 (CBF, MBF) を測定した。

また, $2 \mathrm{~g} / \mathrm{kg}$ のマニトールを $20 \%$ 溶液として投与し， その前後に拈いて $\mathrm{RBF}, \mathrm{CBF}, \mathrm{MBF}$ を同様に測定,さ 
らに一側尿管を結禁し, 腎孟内圧を上昇させ, RBF 等 の変化を測定し，以下のような結果を得た。

I. 腎孟内圧 $25 \mathrm{mmHg}$ 上昇群 (水素クリアランス法 により測定）

$\mathrm{RBF}$ は平均 $7.9 \%$ の増加を示したが, $\mathrm{CBF}\left(\mathrm{CH}_{2}\right)$, $\mathrm{MBF}\left(\mathrm{CH}_{2}\right)$ は有意の変化を認めず, 腎孟内圧上昇を 解除すると，それらの全てが上昇前の值に復した。

II. 同じく $50 \mathrm{mmHg}$ 上昇群 (水素クリアランス法に より測定）

$\mathrm{RBF}$ は平均 $11.4 \%$ の増加を示したが, $\mathrm{CBF}\left(\mathrm{CH}_{2}\right)$, $\mathrm{MBF}\left(\mathrm{CH}_{2}\right)$ は有意の変化を示さず, 内圧上昇解除後 は $25 \mathrm{mmHg}$ 上昇群之同様，上昇前の值に戻った。

III. 同じく $75 \mathrm{mmHg}$ 上昇群 (水素クリアランス法 により測定）

$\mathrm{RBF}$ は $8.2 \%$ の増加を示し, 解除後は上昇前值に 戻った。しかし $\mathrm{CBF}\left(\mathrm{CH}_{2}\right), \mathrm{MBF}\left(\mathrm{CH}_{2}\right)$, 共にそれ ぞれ $10.4 \% ， 21.3 \%$ の減少を示し, 解除後は上昇前に ほぼ復した。

IV. 同じく $25 \mathrm{mmHg}$ 上昇群（熱電対法により測定） $\mathrm{RBF}$ は $12.0 \%$ の有意の増加をみたが, $\mathrm{CBF}$ (Th), $\mathrm{MBF}(\mathrm{Th})$ は有意の変化をみなかった.

V. 同じく $75 \mathrm{mmHg}$ 上昇群 (熱電対法により測定)

$\mathrm{RBF}$ は $13.3 \%$ の増加をみた。 また, $\mathrm{CBF}$ ( Th)は平 均 $19.2 \%$ の有意の増加を認め, MBF (Th) は4.8\%の 増加をみたが有意の変化ではなかった。

VI. マニトール投与後の尿管結紮群

マニトール投与後は投与前と比較して, RBF が平均 $39.0 \%, \mathrm{CBF}\left(\mathrm{CH}_{2}\right)$ が $21.4 \%, \mathrm{MBF}\left(\mathrm{CH}_{2}\right)$ が $26.2 \%$ の増加を示し, $\mathrm{CBF}$ (Th) は $33.85 \%, \mathrm{MBF}(\mathrm{Th})$ は $25.2 \%$ 増加をみた。 また, 尿管結紮後, 腎孟内圧は すみやかに80 100 $\mathrm{mmHg}$ に上昇し，マニトール投与 後に比して RBF は21.2\%, $\mathrm{CBF}\left(\mathrm{CH}_{2}\right)$ は27.5\%, $\operatorname{MBF}\left(\mathrm{CH}_{2}\right)$ は $34 \%, \mathrm{CBF}(\mathrm{Th})$ は $39.3 \%, \mathrm{MBF}(\mathrm{Th})$ は30\%の減少をみた。更に，尿管結禁を解除し，結禁 前と比較すると, $\mathrm{RBF} か 331.1 \%, \mathrm{CBF}\left(\mathrm{CH}_{2}\right)$ は $34.1 \%, \mathrm{CBF}$ （Th）は43.9\%の有意の減少であり, $\mathrm{MBF}\left(\mathrm{CH}_{2}\right)$ は28.15\%, MBF (Th) は $13.7 \%$ の減少 を示したが有意の変化はなかった.

以上の結果より, 腎孟内圧の急激な上昇が腎血流に 与える影響についてまとめてみると，

（1）腎盂内圧上昇の程度と $\mathrm{RBF}$ の増加度に，特に 相関は認められなかった。

(2) $25 \mathrm{mmHg}, 50 \mathrm{mmHg}, 75 \mathrm{mmHg}$ のそれぞれの腎 孟内圧上昇群に打ける測定結果より, 皮質内には腎孟
内圧上昇群に応じて開放されるいわゆる non-nutrient flow が，閉塞腎の血行動態に大きく関与していると考 えられた。

（3）髄質血流は腎孟内圧の高度上昇により，水素ク リアランス法では大きく減少した。これは前に述べた non-nutrient flow が直接静脈側に流入し, 結果的に静 脈性 Vasa Recta 血行の停滞をもたらすためと考觉ら れた。

（4）マニトール負荷により RBF とともにいずれの 測定法でも皮質, 髄質の組織血流が増加したが，これ は従来の wash out theory を更に強く裏づけるものと 思われた。

（5）マニトール負荷の状態で尿管を結禁すると $\mathrm{RBF}$ 拈よび $\mathrm{CBF}\left(\mathrm{CH}_{2}\right), \mathrm{CBF}(\mathrm{Th})$ は大きく减少し た. $\mathrm{MBF}\left(\mathrm{CH}_{2}\right), \mathrm{MBF}(\mathrm{Th})$ の低下については, 能 動的作用であるか，もしくは受動的結果であるかは断 定できなかった。

（6）マニトール負荷後に尿管結禁を行い，一定時間 おいて解除しても，マニトール非負荷群のようには血 流は戻らず，このような操作が腎に対し回復不能な程 の侵襲を与えることが判明した。

最後に従来より用いられている諸種の組織血流量測 定法について若干の検討を加えた。

稿を終るにあたり，御指導ならびに御校関を賜った恩師 土田正義教授に深甚なる謝意を表すると共に，直接御指導 を賜った原田忠講師に深く感謝致します。更に実験に御協 力頂いた加藤隆三技官ならびに当教室諸兄に深く感謝致し ます。

な括, 本論文の要旨は第23回, 日本腎臓学会総会に扔いて 発表した。

\section{文献}

1) Bay, W.H., et al.: Redistribution of renal cortical blood flow during elevated ureteral pressure. Am. J. Physiol., 222, 33-37, 1972.

2) Suki, W.N., et al. : Effects of ureteral pressure elevation on renal hemodynamics and ureine concentration. Am. J. Physiol., 220, 38-43, 1971.

3) Selkurt, E.E. : Effect of ureteral blockade on renal blood flow and urinary concentrating ability. Am. J. Physiol., 205, 286-292, 1963.

4) Carlson, E.L.: Intrarenal distribution of blood flow during elevation of ureteral pressure in dogs. Circ. Res., 26, 601-610, 1970.

5) Hársing, L., et al.: Renal circulation during stop flow in the dog. Am. J. Physiol., 213, 
935-938, 1967.

6) Abe, Y., et al.: Intrarenal distribution of blood flow during ureteral and venous pressure elevation. Am. J. Physiol., 224, 746-751, 1973.

7) Vaughan, E.D., et al.: Mechanism of acute hemodynamic response to ureteral occlusion. Invest. Urol., 9, 109-118, 1971.

8) Solez, K., et al.: Inner medullary plasma flow in the kidney with ureteral obstruction. Am. J. Physiol., 231, 1315-1321, 1976.

9) Aukland, K., et al.: Measurement of local blood flow with hydrogen gas. Circ. Res., 14, 164-187, 1963.

10）田村 晃, 他：水素クリアランス法による脳局所 血流量の測定. 脳神経, $30,47-53,1978$.

11）佐藤重樹：水素クリアランス法による小腸局所血 流量と虚血腸管生存性の関係について。脈管学, 20, 777-783, 1980.

12）宮本二郎，他：内視鏡を応用した胃粘膜下組織血 流量の測定. Progress of Digestive Endoscopy, 14, 57-61, 1979.

13）跡見 裕, 他：腪血流量測定法. 日本臨床, 37, 1081-1082, 1979.

14）高橋 功, 萩原弥四郎：交叉熱電対法による腎皮 質怙よび髄質の局所循環の研究. 日薬理誌, 65, 228-235, 1969.

15) Hyman, E.S. : Linear system for quantitating hydrogen at a platinum electrode. Circ. Res., 9, 1093-1097, 1961.

16) Levy, S.E., et al.: The effect of ureteral occlusion on the blood flow and oxygen consumption of the kidneys of unanesthetized dog. Surgery, 1, 238-242, 1937.

17) Vaughan, E.D., et al.: The renal hemodynamic response to chronic unilateral complete ureteral occlusion. Invest. Urol., 8, 78-90, 1970.

18) Murphy, G.P. and Scott, W.W.: The renal hemodynamic response to acute and chronic ureteral occlusions. J. Urol., 95, 636-637, 1966.

19) Moody, T.E., et al.: Relationship between renal blood flow and ureteral pressure during 18 hours of total unilateral ureteral occlusion. Invest. Urol., 13, 246-251, 1975.

20) Thurau, K.: Renal hemodynamics. Am. J. Med., 36, 698-719, 1964.

21) Allen J.T., et al.: The effect of indomethacin on renal blood flow and ureteral pressure in unilateral ureteral obstruction in awakes dogs. Invest. Urol., 15, 324-326, 1978.

22）武内重五郎: 臨床腎臟病学 1-18. 南江堂, 東京, 1975.
23）須永俊明：腎循環. Medicina, 19, 529-535, 1982.

24) Munkácsi, I., et al.: Vascular shunts in the renal cortex of the dog. Rev. Can. Biol., 22, 353-363, 1963.

25) Takazakura, E., et al.: Intrarenal vascular changes with age and disease. Kidney International, 2, 224-230, 1972.

26) Barie, H.J., et al. : Direct medullary arterioles and arteriovenous anastomoses in the arcuate sponges of the kidney. Lancet, 1, 23, 1950.

27）竹内 正, 森 吉臣: 循環. 391-457, 文光堂, 東 京, 1980 .

28) Stein, J.H., et al.: Differences in the effect of furosemide and chlorothiazide on the distribution of renal cortical blood flow in the dog. J. Labo. Clin. Med., 79, 995-1003, 1972.

29) McNay, J.L. and Abe, Y.: Redistribution of cortical blood flow during renal vasodilatation in dogs. Cric. Res., 27, 1023-1032, 1970.

30) Velasquez, M.T., et al.: Comparative effects of saline and mannitol on renal cortical blood flow and volume in the dog. Am. J. Physiol., 224, 322-327, 1973.

31) Pilkington, L.A., et al. : Intrarenal distribution of blood flow. Am. J. Physiol., 208, 1107-1113, 1965.

32) Ayer, G., et al.: Intrarenal hemodynamics in glycerolinduced myohemoglobinuric acute renal failure in the rat. Circ. Res., 29, 128-135, 1971.

33) Castaneda-Zuniga, W.R., et al.: Renal blood flow changes following mannitol infusion. Rev. Interamerica de Radiologia, 3, 21-26, 1978.

34) Hope, A., et al.: Intrarenal distribution of blood flow in rats determined by ${ }^{125}$. Iodoantipyrine uptake. Circ. Res., 39, 362-370, 1976.

35) Perl, W. and Hirsch, R.L. : Local blood flow in kidney tissue by heat clearance measurement. J. Therorct. Biol., 10, 251-280, 1966.

36）山本研二郎, 安部陽一: 腎内血流分布. 最新医学, 29, 2105-2113, 1974.

37) Hamburger, J., et al.: Nephrology, W.B. Saunders Company, Philadel Phia., London, Toronto, 1968.

38) Gilmore, J.P.: Influence of tissue pressure on renal blood flow autoregulation. Am. J. Physiol., 206, 707-713, 1964.

39) Selkurt, E.E., et al. : Mechanism of natriuresis and diuresis during elevated renal arterial pressure. Am. J. Physiol., 209, 95-99, 1965.

40) Naber, K.G. and Madsen, P.O. : Renal function 
during acute total ureteral occlusion and the role of the lymphatics: An experimental study in dogs. J. Urol., 109, 330-337, 1973.

41）芝 伸彦：尿管完全閉塞の尿生成機序に招上ぼす 影響について. 日泌尿会誌, 68, 1204-1213， 1977.

42) Birtch, A.G., et al.: Redistribution of renal blood flow produced by furosemide and ethacrynic acid. Circ. Res., 21, 869-878, 1967.

43) Thurau, K. and Levine, A. : In the kidney, ed. by Rouiller, C. and Muller, A.F., Vol. III. Acad. Press, New York, 1971.

44) Dibona, G.F.: Effect of mannitol diuresis and ureteral occlusion on distal tubular reabsorption. Am. J. Physiol., 221, 511-514, 1971.

45) Ploth, D.W. and Naver, L.G.: Intrarenal effects of the renin-angiotensin system. Fed. Proc., 38, 2280-2285, 1979.

（1984年 2 月 29 日受付，特別掲載） 